affect the development of the labor market, in particular on its supply and demand. In terms of the number of registered unemployed and the number of vacancies for the period 2019-2020, the negative impact of the COVID-19 pandemic on the labor market has been determined. The date of the State Employment Service, which determined the need for staff for 2021 by type of economic activity (in the processing industry, agriculture, trade, education, transport and warehousing, public administration and defense) and the structure of demand for workers by the main sections of the classification of the professions. The number of vacancies and their structure in the Donetsk region for the period 20182021 are analyzed. It is noted that in today's realities one of the main problems of the domestic labor market is youth employment. It is determined that the current segment of youth employment in Ukraine is characterized by a number of problems, for example: low level of economic activity of the youngest age group; high unemployment, which decreases in older age groups of young people; structural imbalance between labor supply and demand; significant level of informal employment and more. The measures taken by the Cabinet of Ministers of Ukraine to ensure youth employment are presented.

\section{ІННОВАЦІЙНИЙ РОЗВИТОК ЕКОНОМІЧНИХ СИСТЕМ: ДЕРЖАВНИЙ I РЕГІОНАЛЬНИЙ АСПЕКТИ ФІНАНСУВАННЯ}

ДЯТЛОВА Ю. В., доктор економічних наук, доцент, завідувач кафедри фінансів та обліку,

ТАРАСЕНКО Д. Л., доктор економічних наук, доцент, декан факультету права і публічного управління, Донецький державний університет управління

\section{INNOVATIVE DEVELOPMENT OF ECONOMIC SYSTEMS: STATE AND REGIONAL FINANCING ASPECTS}

\author{
DIATLOVA Yu., \\ Doctor of Science in Economics, \\ Associate Professor, Head of the \\ Department of Finance and \\ Accounting \\ TARASENKO D., \\ Doctor of Science in Economics, \\ Associate Professor, Donetsk State \\ University of Management
}

Встановлено сучасні тенденції фінансування інноваційного розвитку економічних систем на рівні держави та регіонів. Акцентовано увагу на специфіці та вкладі регіонів у створення фінансових передумов інноваційного розвитку. Показано, що недосконалість механізму фінансового стимулювання зумовлює нерозвиненість інноваційної інфраструктури та обмеженість ії участі в інноваційних процесах. Запропоновано рівні пріоритетів фінансування інноваційної діяльності та відповідні їм джерела. Обгрунтовано розширення номенклатури показників.

Ключові слова: інноваційний розвиток економіки, державний $і$ регіональний аспекти, фінансове забезпечення, джерела, банківське фінансування, рівні пріоритетів, показники. 


\begin{abstract}
Установлены современные тенденции финансирования инновационного развития экономических систем на уровне государства и регионов. Акцентировано внимание на специфике и вкладе регионов в создание финансовых предпосылок инновационного развития. Показано, что несовершенство механизма финансового стимулирования обусловливает неразвитость инновационной инфраструктуры и ограниченность ее участия в инновационных процессах. Предложены уровни приоритетов финансирования инновационной деятельности и соответствующие им источники. Обосновано расширения номенклатуры показателей.
\end{abstract}

Ключевые слова: инновационное развитие экономики, государственный и региональный аспекты, финансовое обеспечение, источники, банковское финансирование, уровне приоритетов, показатели.

The modern trends in financing the innovative development of economic systems at the state and regional level have been established. Attention is focused on the specificity and contribution of regions to the creation of financial prerequisites for innovative development. It is shown that the imperfection of the financial incentive mechanism determines the underdevelopment of the innovation infrastructure and the limited participation of it in innovation processes. The levels of priorities for financing innovation activities and the corresponding sources are proposed. The expansion of the indicators nomenclature is substantiated.

Key words: innovative development of economy, state and regional aspects, financial provision, sources, bank financing, levels of priorities, indicators.

Постановка проблеми. В останні роки, як свідчить досвід країн світових лідерів, сталий розвиток національних економічних систем базується на дослідженнях і розробках, нових знаннях, високотехнологічному виробництві та інноваційній продукції. Країни докладають зусиль щодо формування інноваційних систем і розвитку інноваційного потенціалу як передумов економічного успіху, забезпечення безпеки в економічній сфері та конкурентоспроможності на світовому рівні. Між тим, економіка України перебуває на периферії процесу інноваційного розвитку, що ніяк не відповідає ресурсним можливостям нашої країни, яка ще 30 років тому була одним із лідерів за деякими високотехнологічними напрямами промислового виробництва. Це активізує науковий пошук у напрямку вирішення проблем інноваційного розвитку національної та регіональних економічних систем.

Аналіз останніх досліджень і публікацій. Проблемам інноваційного розвитку економіки присвячені праці багатьох вітчизняних та зарубіжних вчених, зокрема в останнє п'ятиріччя таких, як А. Антохов [1], В. Геєць [2], В. Дятлова [3], М. Зось-Кіор [4], І. Штулер [5] та ін. Фінансовому забезпеченню інноваційного розвитку економіки приділили увагу І. Алєксєєв [6], Г. Бадрі [7], Н. Демчишак [8], Я. Пилип'юк [9] та ін. Між тим, динамічні зміни в інноваційній сфері потребують акцентувати увагу на регіональній специфіці та розвитку джерел фінансування.

Мета статті полягає в обґрунтуванні фінансових передумов інноваційного розвитку національних та регіональних економічних систем, підходів до визначення рівнів фінансування і відповідних їм джерел і показників.

Виклад основного матеріалу дослідження. Інноваційний розвиток країн оцінюється за індексом інновацій. За рейтингом Глобального індексу інновацій 2020 до ТОП-5 найбільш інноваційних країн увійшли 
Швейцарія, Швеція, США, Велика Британія, Нідерланди. Україна посіла 45 місце серед 131 країни світу. Для порівняння: у 2018 році Україна мала 43 ранг, у 2019 році - 47. Це вказує на більш-менш стабільні позиції та на необхідність застосування більш ефективних інструментів, зокрема щодо фінансового стимулювання інноваційної діяльності.

Інноваційний розвиток економічної системи країни оцінюється за різними показниками, однак найбільш результуючим показником $€$ обсяги виробництва і реалізації інноваційної продукції. В Україні питома вага реалізованої інноваційної продукції в обсязі промислової становила $3,3 \%$ у 2012 р., у $2014-2,5 \%$, а у $2019-0,9 \%$. Інноваційність економічної системи країни залежить від регіональних складових. За показником частки реалізованої інноваційної продукції, в обсязі промислової, регіони значно розрізняються (рис. 1).

Найбільш вагомий внесок у результуючий показник щодо реалізованої інноваційної продукції по країні внесено у 2014 році Сумською, Полтавською та Закарпатською областями. У 2019 році лідерами стали Донецька та Кіровоградська області, однак значення їх часток майже вдвічі є меншим, ніж у 2014 році. Тенденції є нестійкими, що обґрунтовує значимість регіональних економічних систем. Крім того, за таких тенденцій зростає роль формування інноваційного потенціалу та створення передумов його реалізації.
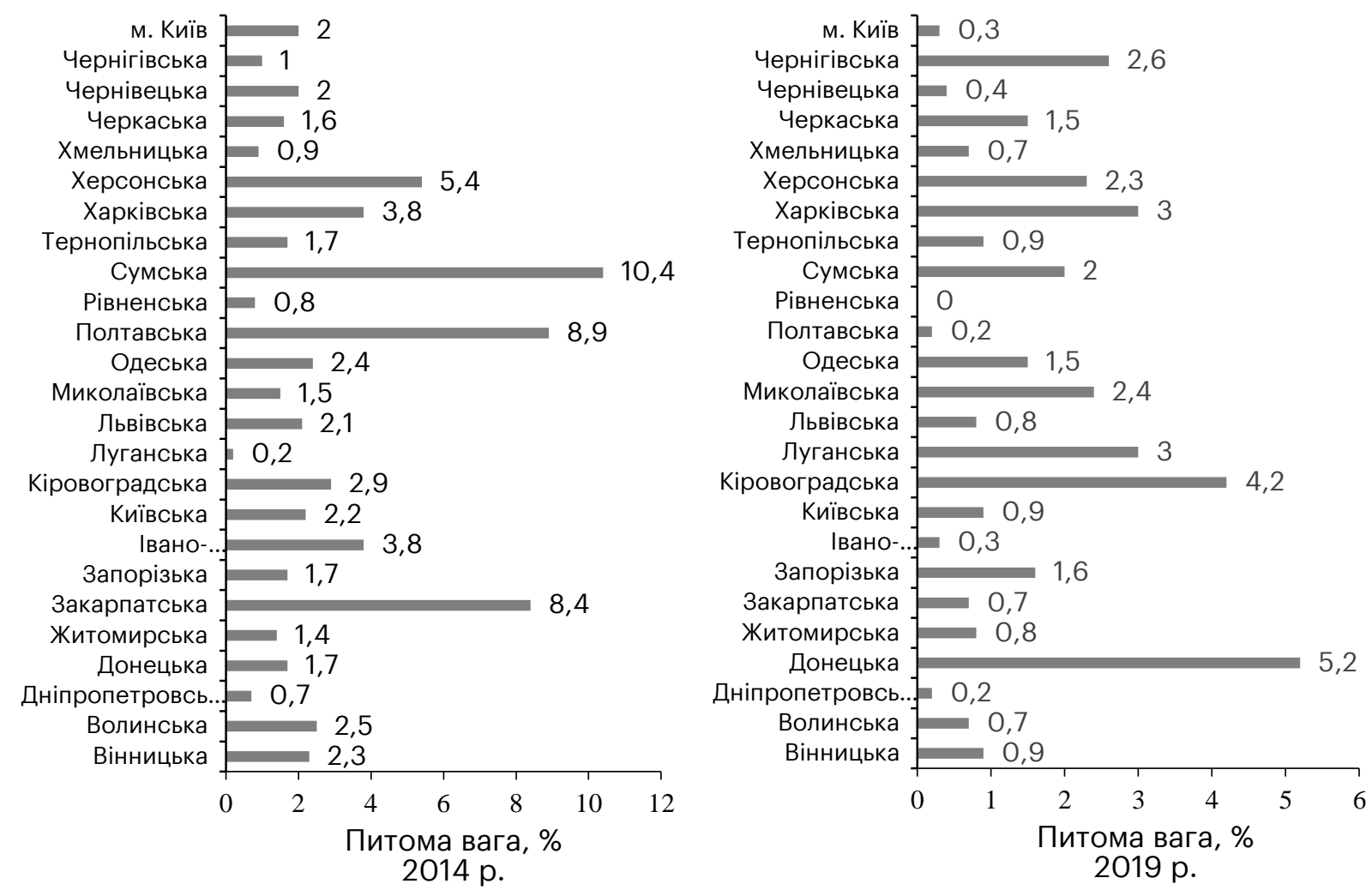

Рис. 1. Питома вага реалізованої інноваційної продукції в обсязі промислової*

Укладено за даними URL: http://www.ukrstat.gov.ua/druk/publicat/kat_ u/2020/zb/09/zb_nauka_2019.pdf. 
Фінансове забезпечення $є$ важливою передумовою інноваційного розвитку економічних систем національного та регіонального рівнів. Структура витрат на виконання наукових досліджень і розробок за джерелами фінансування свідчить (табл. 1), що у 2019 році найбільш вагомою є частка коштів бюджету - майже 40\%, а власні кошти, які вкладають підприємства - лише 10\%. Іноземне інвестування збільшилося до 22,4\%. 3 інфраструктурних джерел значною $€$ частка коштів організацій підприємницького сектору - 23,4\%. Менше відсотка у фінансуванні наукових досліджень і розробок припадає як на приватні некомерційні організації, так і організації сектору вищої освіти, а також на кошти інших джерел.

Таблиця 1

Витрати на виконання наукових досліджень і розробок у 2019 році за джерелами фінансування

\begin{tabular}{|c|c|c|}
\hline Вид витрат & $\begin{array}{c}\text { Сума витрат, тис. } \\
\text { грн }\end{array}$ & $\begin{array}{c}\text { Питома вага, } \\
\%\end{array}$ \\
\hline Кошти бюджету & 6724744,9 & 38,97 \\
\hline з них державного бюджету & 6603856,1 & 38,27 \\
\hline Власні кошти & 1725112,0 & 10,00 \\
\hline Кошти організацій державного сектору & 798621,8 & 4,63 \\
\hline $\begin{array}{l}\text { Кошти організацій підприємницького } \\
\text { сектору }\end{array}$ & 4035650,1 & 23,39 \\
\hline Кошти організацій сектору вищої освіти & 3709,6 & 0,02 \\
\hline $\begin{array}{l}\text { Кошти приватних некомерційних } \\
\text { організацій }\end{array}$ & 14662,6 & 0,08 \\
\hline Кошти іноземних джерел & 3856175,0 & 22,35 \\
\hline Кошти інших джерел & 95953,7 & 0,56 \\
\hline Усього & 17254629,7 & $100 \%$ \\
\hline
\end{tabular}

Вклад регіонів у фінансування наукових досліджень і розробок значно розрізняється (табл. 2). До ТОП-5 у 2014 році входили м. Київ, Харківська, Дніпропетровська, Запорізька та Миколаївська області, їх частка в сукупності - 85\%. У 2019 році. Львівська область замінила в цьому рейтингу Миколаївську область. Їх сукупна частка збільшилася до 90\%. При цьому на м. Київ припадає майже 50\%. Запорізька область суттєво збільшила свою частку, майже вдвічі. Однак є області, на які припадає менше відсотка: у 2014 році таких було 15, у 2019 році - 17 областей. Рівненська та Волинська області вносять найменший внесок у фінансування наукових досліджень і розробок.

Таблиця 2

Витрати на виконання наукових досліджень і розробок за регіонами*, тис. грн

\begin{tabular}{|l|c|c|c|c|c|}
\hline \multicolumn{1}{|c|}{ Область } & $\begin{array}{c}2014 \text { р., } \\
\text { тис. грн }\end{array}$ & $\begin{array}{c}\text { Питома } \\
\text { вага, \% }\end{array}$ & $\begin{array}{c}2019 \text { р., } \\
\text { тис. грн. }\end{array}$ & $\begin{array}{c}\text { Питома } \\
\text { вага, \% }\end{array}$ & $\begin{array}{c}\text { Приріст, } \\
\%\end{array}$ \\
\hline Вінницька & 34247,9 & 0,35 & 39618,3 & 0,23 & 15,68 \\
\hline Волинська & 10361,2 & 0,11 & 9948,3 & 0,06 & $-3,99$ \\
\hline Дніпропетровська & 1179175,0 & 12,12 & 2310005,8 & 13,39 & 95,90 \\
\hline Донецька & 244857,6 & 2,52 & 32503,1 & 0,19 & $-86,73$ \\
\hline Житомирська & 19137,9 & 0,20 & 26372,1 & 0,15 & 37,80 \\
\hline Закарпатська & 31446,9 & 0,32 & 77694,5 & 0,45 & 147,07 \\
\hline Запорізька & 472352,2 & 4,86 & 1538449,8 & 8,92 & 225,70 \\
\hline $\begin{array}{l}\text { Івано- } \\
\text { Франківська }\end{array}$ & 21040,5 & 0,22 & 42107,7 & 0,24 & 100,13 \\
\hline Київська & 174094,0 & 1,79 & 417736,0 & 2,42 & 139,95 \\
\hline Кіровоградська & 32467,1 & 0,33 & 24873,6 & 0,14 & $-23,39$ \\
\hline
\end{tabular}




\begin{tabular}{|c|c|c|c|c|c|}
\hline \multicolumn{6}{|c|}{ Продовження табл. 2} \\
\hline Луганська & 54906,2 & 0,56 & 39288,4 & 0,23 & $-28,44$ \\
\hline Львівська & 265712,8 & 2,73 & 465522,2 & 2,70 & 75,20 \\
\hline Миколаївська & 328471,0 & 3,38 & 236640,0 & 1,37 & $-27,96$ \\
\hline Одеська & 175870,7 & 1,81 & 342214,1 & 1,98 & 94,58 \\
\hline Полтавська & 44420,2 & 0,46 & 44639,3 & 0,26 & 0,49 \\
\hline Рівненська & 9918,2 & 0,10 & 17619,0 & 0,10 & 77,64 \\
\hline Сумська & 134509,3 & 1,38 & 93616,4 & 0,54 & $-30,40$ \\
\hline Тернопільська & 11396,6 & 0,12 & 29094,1 & 0,17 & 155,29 \\
\hline Харківська & 1981281,0 & 20,37 & 2864158,6 & 16,60 & 44,56 \\
\hline Херсонська & 40464,3 & 0,42 & 72220,1 & 0,42 & 78,48 \\
\hline Хмельницька & 14564,7 & 0,15 & 19233,7 & 0,11 & 32,06 \\
\hline Черкаська & 56941,0 & 0,59 & 52040,2 & 0,30 & $-8,61$ \\
\hline Чернівецька & 42872,3 & 0,44 & 105729,7 & 0,61 & 146,62 \\
\hline Чернігівська & 39317,2 & 0,40 & 46342,6 & 0,27 & 17,87 \\
\hline М. Київ & 4307042,6 & 44,28 & 8306962,0 & 48,14 & 92,87 \\
\hline Україна & 9726868,4 & 100 & 17254630,0 & 100 & 77,39 \\
\hline
\end{tabular}

*Без урахування тимчасово окупованої території Автономної Республіки Крим, м. Севастополя та частини тимчасово окупованих територій у Донецькій та Луганській областях

Укладено за даними URL: http://www.ukrstat.gov.ua/druk/publicat/kat_ u/2020/zb/09/zb_nauka_2019.pdf.

Джерела фінансування можна згрупувати за рівнями (макро, мезо, мікро). На макрорівні пріоритетом $€$ фінансування фундаментальних досліджень. Розробка національної стратегії та визначення пріоритетів інноваційного розвитку $\epsilon$ прерогативою держави. Так, прийнята Стратегія розвитку сфери інноваційної діяльності на період до 2030 року ставить за мету утворити національну інноваційну екосистему [10]. Держава в правовому аспекті повинна забезпечити умови та стимули для здійснення інноваційної діяльності суб'єктами господарювання. Існуючий механізм фінансового стимулювання інноваційної діяльності не $€$ достатньо дієвим, зокрема через обмеженість податкових та кредитних стимулів, що не сприяють створенню необхідних умов для здійснення модернізації національної економіки на інноваційних засадах. Тенденції надання кредитів підприємствам під інвестиційні проєкти свідчать про розбіжність інтересів реального сектору економіки та банківських установ [11]. Так, відсоткові ставки кредитування $€$ значними та за більшістю перевищують можливості інвестиційних проєктів, зокрема 3 урахуванням їх норм рентабельності, ризиків і довготривалості.

На мезорівні бюджетне фінансування $є$ незначним (у 2019 році становило менше відсотка). На регіональному рівні влада має можливість стимулювати інноваційну діяльність через програми, міжнародні гранти, створення платформ вітчизняних інвесторів. Слід зазначити, що держава, проводячи політику децентралізації, деякою мірою передає функції забезпечення інвестиціями на рівень регіонів та суб'єктів господарювання. Це сприяє підвищенню ролі регіональних органів влади у створенні інноваційної інфраструктури як пріоритетному напрямі. Саме нерозвинена інфраструктура (наявність наукових, технологічних та індустріальних парків, кластерів, інноваційних центрів, науково-навчальних центрів, навчальних науково-виробничих комплексів, інноваційних бізнес-інкубаторів, центрів інновацій і трансферу технологій, центрів комерціалізації інтелектуальної власності, консультаційних центрів 3 питань 
інноваційної діяльності) стала підґрунтям щодо наявності регіонів 3 малочисельним вкладом у фінансування наукових досліджень і розробок. Тільки регіональних центрів з інвестицій та розвитку, яких налічується 27, а також майже 1100 венчурних фондів можна вважати достатніми за кількістю.

На мікрорівні джерелами фінансування інноваційної діяльності $€$ власні кошти, позикові та залучені засоби. Самофінансування за рахунок амортизаційних відрахувань, мобілізації внутрішніх активів, виручки від реалізації окремих видів майна, нерозподіленого прибутку та інших накопичень $€$ пріоритетним через незалежність від різних зобов'язань. Як залучені засоби можуть бути використані бюджетні кошти державного й місцевого рівнів, емісія акцій, вітчизняні та іноземні інвестиції - програми, міжнародні гранти, кошти іноземних інвесторів і іноземних фондів. Позикові засоби, такі як довгострокові кредити банківських і інших фінансових установ, лізинг, форфейтинг, франчайзинг можуть мати різну значимість з точки зору пріоритетності в залежності від договірних зобов'язань.

Встановлення чітких пріоритетів на всіх рівнях і їх економічне обґрунтування на рівні суб'єктів господарювання, об'єднання зусиль надасть можливість забезпечити ефективне фінансування наукових досліджень і розробок. Сприятиме цьому й моніторинг та систематичний контроль ефективності фінансування інноваційного розвитку економічних систем за певними показниками.

Державна служба статистики наразі використовує показники, які характеризують інноваційний потенціал та фінансове забезпечення його реалізації. Науковцями застосовується більша сукупність показників [12]. На наш погляд, сучасна номенклатура показників не достатньо конкретизує джерела фінансування, оскільки не акцентує уваги на структурі коштів щодо позикових та залучених. Крім того, необхідно застосовувати відносні показники щодо валового внутрішнього продукту, валового регіонального продукту, ефективності вкладених засобів у національні інноваційні проєкти, регіональні проєкти, в інноваційну діяльність суб'єктів господарювання, зокрема співвідношення обсягів реалізованої інноваційної продукції і витрат на інноваційну діяльність та інших.

Висновки і перспективи подальших досліджень. Таким чином, у результаті аналізу фінансових передумов інноваційного розвитку національної та регіональних економічних систем встановлено наступне. За питомою вагою реалізованої інноваційної продукції в обсязі промислової, який $€$ результуючим показником щодо інноваційної діяльності, тенденції на рівні країни та більшості регіонів $€$ негативними. Найбільший вклад в інноваційну діяльність по країні вносять окремі області, але тенденції є нестійкими, що обґрунтовує значимість регіональних економічних систем.

Фінансове забезпечення $€$ важливою передумовою інноваційного розвитку економічних систем. Структура витрат на виконання наукових досліджень і розробок за джерелами фінансування свідчить, що кошти бюджету наразі залишаються вагомими за часткою. Вклад регіонів у фінансування наукових досліджень і розробок значно розрізняється, при цьому є значна кількість областей, на які припадає менше відсотка в загальному обсязі по Україні. Запропоновано рівні пріоритетів фінансування інноваційної діяльності та відповідні їм джерела. Зокрема, на державному рівні пріоритетом $€$ фінансування 
фундаментальних досліджень, створення нормативно-правового підґрунтя. На регіональному рівні пріоритетним $\epsilon$ створення інноваційної інфраструктури, нерозвиненість якої обмежує її участь в фінансуванні. Також обґрунтовано розширення номенклатури показників.

Література:

1. Антохов А. А., Котельбан С. В. Регулювання інноваційного розвитку економіки в умовах глобалізації: зміст, методи, інструменти. Інноваційна економіка. 2019. № 1-2(78). С. 25-31.

2. Геєць В.М. Економіка України: ключові проблеми і перспективи. Економіка і прогнозування. 2016. № 1. С. 7-22

3. Дятлова В. В., Петрик І. В. Інноваційний потенціал економіки: методичний підхід до оцінки та групування регіонів. Держава та регіони. Серія «Економіка та підприємництво». 2018. № 1(100). С. 106-112.

4. Зось-Кіор М.В., Співак С.І., Калита Є.О. Управління інвестиційно-інноваційною діяльністю в контексті формування умов стійкого розвитку. Інтернаука. Серія «Економічні науки». 2017. № 5. C. 65-69.

5. Shtuler I., Cherlenyak I., Domyshche-Medyanik A., Voitovych S. Conditions of formation and stimulation of the activators of innovative development of Ukraine. Problems and Perspectives in Management. 2017. № 15(4). P. 150-160.

6. Алєксєєв І. В., Паранчук С. В., Червінська О. С. Інноваційний розвиток підприємств регіону та його фінансове забезпечення. Регіональна економіка. 2012. № 2. С. 99-108.

7. Бадрі Г., Панченко Є., Рудуха Н. Глобальні детермінанти і моделі фінансування інновацій. Міжнародна економічна політика. 2018. № 1 (28). С. 7-31.

8. Демчишак Н.Б. Фінансове регулювання інноваційної діяльності в Україні: монографія. Львів: ЛНУ імені І. Франка, 2016. 494 c.

9. Pylypyuk Ya., Fedyshyn I. Mechanism of Financial Support of Innovative Activities in Ukraine. International Journal of Economics and Society. USA, 2015. Vol. 1, Issue 2. Р. 169-175.

10. Стратегія розвитку сфери інноваційної діяльності на період до 2030 року. URL: https://zakon.rada.gov.ua/laws/show/526-2019$\%$ D1\%80\#Text.

11. Рекова Н.Ю., Дятлова Ю. В. Розвиток кредитування реального сектору економіки: фокус на АПК як пріоритетну галузь. Фінансовий простір: електронне наукове фахове видання. 2019. № 1 (33). C. 8 17. URL: https://fp.cibs.ubs.edu.ua/index.php/fp/article/view/6 72.

12. Колодізєв О.М. Формування багаторівневої системи показників фінансування інноваційної діяльності. Актуальні проблеми економіки. 2013. № 8(146). С. 32-44.

\section{References:}

1. Antokhov A. A., Kotelban S. V. Rehuliuvannia innovatsiinoho rozvytku ekonomiky v umovakh hlobalizatsii: zmist, metody, instrumenty. Innovatsiina ekonomika. 2019. № 1-2 (78). S. 25-31.

2. Heiets V. M. Ekonomika Ukrainy: kliuchovi problemy i perspektyvy. Ekonomika i prohnozuvannia. 2016. № 1. S. 7-22. 
3. Diatlova V. V., Petryk I. V. Innovatsiinyi potentsial ekonomiky: metodychnyi pidkhid do otsinky ta hrupuvannia rehioniv. Derzhava ta rehiony. Seriia "Ekonomika ta pidpryiemnytstvo". 2018. № 1 (100). S. 106-112.

4. Zos-Kior M. V., Spivak S. I., Kalyta Ye. O. Upravlinnia investytsiino-innovatsiinoiu diialnistiu $v$ konteksti formuvannia umov stiikoho rozvytku. Internauka. Seriia "Ekonomichni nauky". 2017. № 5. S. 65-69.

5. Shtuler I., Cherlenyak I., Domyshche-Medyanik A., Voitovych S. Conditions of formation and stimulation of the activators of innovative development of Ukraine. Problems and Perspectives in Management. 2017. No 15(4). P. 150-160.

6. Alekseyev I. V., Paranchuk S. V., Chervinska O. S. Innovatsiinyi rozvytok pidpryiemstv rehionu ta yoho finansove zabezpechennia. Rehionalna ekonomika. 2012. № 2. S. 99-108.

7. Badri H., Panchenko Ye., Rudukha N. Hlobalni determinanty i modeli finansuvannia innovatsii. Mizhnarodna ekonomichna polityka. 2018. № 1 (28). S. 7-31.

8. Demchyshak N. B. Finansove rehuliuvannia innovatsiinoi diialnosti v Ukraini: monohrafiia. Lviv: LNU imeni I. Franka, 2016. $494 \mathrm{s.}$

9. Pylypyuk Ya., Fedyshyn I. Mechanism of Financial Support of Innovative Activities in Ukraine. International Journal of Economics and Society. USA, 2015. Vol. 1, Issue 2. P. 169-175.

10. Stratehiia rozvytku sfery innovatsiinoi diialnosti na period do 2030 roku. URL: https://zakon.rada.gov.ua/laws/show/526-2019\%D1\%80\#Text.

11. Rekova N. Yu., Diatlova Yu. V. Rozvytok kredytuvannia realnoho sektoru ekonomiky: fokus na APK yak priorytetnu haluz. Finansovyi prostir: elektronne naukove fakhove vydannia. 2019. № 1 (33). S. 8-17. URL: https://fp.cibs.ubs.edu.ua/index.php/fp/article/view/672.

12. Kolodiziev O. M. Formuvannia bahatorivnevoi systemy pokaznykiv finansuvannia innovatsiinoi diialnosti. Aktualni problemy ekonomiky, 2013. № 8(146). S. 32-44.

The relevance of the study lies in the need to solve the problems of innovative development of national and regional economic systems. Scientific research in this direction is actualized by the fact that the Ukrainian economy is on the periphery of the process of world innovative development, and this does not correspond to the resource potential of the country. The article aims to substantiate the financial prerequisites for the innovative development of national and regional economic systems, approaches to determining the levels of funding and the corresponding sources and indicators.

As a result of the study, it was found that in terms of the share of sold innovative products in the industrial volume, which is the resultant indicator of innovation activity, trends at the level of the country and most regions are negative. The city of Kiev and some regions make the greatest contribution to the innovation activity in the country. In 2019, Donetsk and Kirovograd regions became such leaders, but the trends are unstable and the leaders are changing.

It has been proven that financial support is an important prerequisite for the innovative development of economic systems. The 
structure of expenditures on research and development by funding sources shows that at present budget funds remain significant in terms of their share in financing innovative activities. The contribution of regions to funding research and development varies considerably. The leaders are the city of Kiev, Kharkov, Dnepropetrovsk, Zaporozhye regions. However, at the same time, there are many regions (in 2019 there were 17 such regions), which account for less than a percent of the total volume in Ukraine.

The level of priorities for financing innovative activities and the corresponding sources are proposed. In particular, at the state level, the priority is to finance fundamental research, create a regulatory framework for the development of innovative activities. The prerogative of the state is the development of a national strategy and determination of priorities for innovative development, the formation of a mechanism for financial incentives for innovative activities. However, the mechanism is not effective enough, in particular due to the limited tax and credit incentives. At the regional level, budgetary funding is negligible. At the regional level, the authorities have the opportunity to stimulate innovation through programs, international grants, and the creation of platforms for domestic investors. Therefore, the priority is the formation of an innovative infrastructure, the underdevelopment of which limits its participation in the financing of innovative activities.

For monitoring and systematic control of financing the innovative development of economic systems, it is proposed to expand the range of indicators. The modern nomenclature of indicators does not focus on the structure of borrowed and involved funds. It is also necessary to apply the relative indicators of financing in relation to gross domestic product, gross regional product, as well as the effectiveness of investments in national and regional innovation projects, in the innovation activities of business entities. 